\title{
LIABILITY OF CORPORATE DIRECTORS
}

There seems to be a great deal of uncertainty as to the exact extent of the obligations which a person assumes towards a corporation and its stockholders when he becomes a director. The theory is simple to the extreme. A corporation can act only through human agencies; the stockholders, who control its policies, are in general too numerous and too scattered to wield this ultimate power directly and so choose periodically a select body, usually from their own numbers, designed to supervise its operations. Each member of this board is supposed to be familiar with the company's affairs, to be personally interested in its advancement and to give matters brought to his attention as careful thought as possible.

Now one of the problems of corporate management is, how to make the average director do the work which in theory belongs to him, and which the stockholders expect him to perform. It is a very familiar fact that men are not only willing but eager to have their names added to boards of trustees or conspicuous committees and are then equally willing to pause complacently and allow someone else to discharge any onerous duties that may be attached to the position. No man's best efforts can be aroused, it seems, unless there is a direct appeal to self-interest, and this, of course, is lacking in the office of a corporation manager.

What might be called the amateur aspect of a directorship has probably increased greatly during recent years. By this is meant the idea that such a position is an avocation, a luxury, a compliment paid to a successful business or professional man, something like the bestowal of an honorary degree. And amid the great variety of other considerations that prevail many have little or nothing to do with the management of the company's affairs. For example, one is elected because a relative is a large stockholder and would be pleased. Another bears an honored or conspicuous name which would look well upon statements. A third has large interests and is rather expected to "bring business." It is tacitly understood that none of these men will be called upon to contribute much of his time, and whatever their value to a corporation as "drawing cards" they represent a very large and perhaps increasing element who take little more interest in its daily transactions than so many 
strangers. IVhen it is considered that as long ago as I89o Mr. Justice Field declared that four-fifths of the wealth of the Country was under corporate control and that the proportion has greatly increased since that time, it would seem that every effort should be made to emphasize the respunsibility which properly belongs to directors.

It must be observed in the first place that there has been no relaxation as far as the statute books are concerned in the theory that directors are to exercise an active if not continuous control over the policy of a company. For example the following is an extract from the New York Penal Code: 1

"A director of a corporation or joint stock association is deemed to have such a knowledge of the affairs of the corporation or association as to enable him to determine whether any act, proceeding or omission of its directors is a violation of this chapter. If present at a meeting of the directors at which any act, proceeding or omission of such directors in violation of this chapter occurs, he must be deemed to have concurred therein unless he at the time causes, or in writing requires, his dissent therefrom to be entered on the minutes of the clirectors. If absent from such meeting, he must be deemed to have concurred in any such violation if the facts constituting such violation appear on the record or minutes of the proceedings of the board of directors and he remains a director of the corporation for six months thereafter without causing, or in writing requiring, his dissent from such violation to be entered on such record or minutes."

This displays a lively sense of responsibility and points out the simple and logical way in which a director may avoid penalties in every case in which a majority of his colleagues undertake a course of action as a board which would subject them to a civil as well as a criminal liability. Primarily each director should attend all meetings. If unable for any reason to do so, an absentee should be required to go over the record and in writing either approve or repudiate any action that had been taken.

Many of the theoretical safeguards, however, have become either dead letters or the merest farce. For example, the provision that directors must be stockholders has become so atrophied that the phrase "qualifying shares" is employed frankly as though it were wholly legitimate and did not signify in its very origin a defiance of the spirit of the provision. For qualifying shares as is well known are merely those which are entered on the books of the company in the names of the several directors who have no stock but are desired as members of the board. So, although the title remains in the

I. $\S 614$. 
company itself they become stockholders as far as the records are concerned and everyone is satisfied.

Two very obvious lines exist along which reforms might proceed. One is to recognize the maxim that everybody's business is nobody's business, and that as long as boards consist of numerous members with raguely defined responsibilities very few will feel any serious sense of personal liability and will be inclined to attend to their duties only so far as it is convenient for them to do so. This proposition is emphasized by the modern rise of executive committees in importance-representing a logical if unconscious trend towards a concentration of responsibility-or perhaps more properly a realization of the difficulty of assembling a numerous body of busy men in a practically volunteer capacity at intervals of such frequency as to render their meetings very serviceable.

The executive committee is merely an inner circle of the board composed usually of those directors who are most accessible, most interested in the operations of the corporation and most familiar with them. It bears the same relation to the full board that an ordinary agent does to his principal and in general its acts are those of the board. In many companies indeed its existence has reduced the directors practically to the level of a ratifying body whose services might easily be discarded. The full board of directors of many a company meet only at rare intervals to glance casually over the transactions of an executive committee of three or five members and approve them in a perfunctory manner. Perhaps then one method of checking some of the present shortcomings would be to establish a low maximum to the number of directors that even a large corporation might have. Thus the feeling of personal responsibility might be intensified by destroying the easy and very human reflection that others who have more time seem to be doing everything that is necessary and there is no occasion for worry or effort.

But the other very simple, if not wholly effectual remedy, would be to define sharply and apply vigorously the penalties which lie ready for indolent directors. It is impossible to read the cases in which this very important branch of the law is discussed without being impressed by the court's conviction of the amateurish character of directorships to which reference has been made. From the gingerly manner in which the question of liability is discussed one would suppose that directors were all trustees of charitable institutions, giving freely of their services and engaged in most self-denying tasks. There seems to be ever present a fear lest honorable and distinguished men will be frightened and refuse to accept positions 
on boards and the wheels of commerce adversely affected if a policy of punishment that is really efficacious be adopted. The canons of directorial responsibility are asserted bravely but almost invariably with a countervailing insistence upon preventing alarm to conscientious directors. Thus in a leading English case ${ }^{2}$ Sir George Jessel remarked: "One must be very careful in administering the law of joint stock companies not to press so hard on honest directors as to make them liable for constructive defaults, the only effect of which would be to deter all men of any property and perhaps all men who have any character to lose, from becoming directors of companies at all. On the one hand, I think the court should do its utmost to bring fraudulent directors to account and on the other hand should also do its best to allow honest men to act reasonably as directors." And in a comparatively early New York case, ${ }^{3}$ Judge Earl remarked of a defendant: "He was simply a director and as such attended some of the meetings of the board of directors. As he was a director must we impute to him for the purpose of charging him with fraud, a knowledge of all the affairs of the company? If the law requires this, then the position of a director in any large corporation, like a railroad, banking, or insurance company, is one of constant peril. The affairs of such a company are generally, of necessity, largely intrusted to managing officers. The directors generally cannot know, and have not the ability or knowledge requisite to learn by their own efforts the true condition of the affairs of the company." Is not this last sentence which the writer has italicized an extraordinary indictment of the entire system? Bouvier defines directors as "persons appointed or elected according to law, authorized to manage and direct the affairs of a corporation," yet here is an eminent court practically declaring that they must not be expected to know or be presumed capable of comprehending the matters over which they are to have control! Why should not so important a position as that of director of a mighty corporation be one of "constant peril?" Is not that exactly what is desired, in order that everyone who consents thus to take charge of the essential interests of other people may feel, to speak popularly, if not technically, that he is a "trustee," subject to the duty of careful attention that is required of all fiduciaries?

Of course there is not much difficulty in the case of deliberate and positive wrong-doing, as, for instance, where the directors of a company met and voted a gratuity to one of themselves, the others

2. In re Forest of Dean Coal Mining Co., ro Ch. Div. 450 .

3. Wakeman v. Dalley, 51 N. Y. 27 . 
being his near relatives, and the action was held fraudulent as a clear violation of trust." The menace resides in the spirit of indifference and carelessness which is so widely prevalent and which exists entirely apart from any wrongful intent.

Now waste, mismanagement and neglect are naturally more conspicuous in "monied" corporations than in those engageti in ordinary mercantile pursuits and the majority of,cases to be found in the reports concern banks and similiar institutions. Perhaps, the leading case in this country is Briggs v. Spaulding, ${ }^{\circ}$ in which, by a vote of five to four, the Supreme Court emphasized the importance of preserving a directorship from even the appearance of danger and hence, unpopularity. The facts in the case were disquieting, but, unfortunately, only too familiar. It was an action by the receiver of a national bank against the directors to enforce their personal liability. For fourteen years no committee of the directors had been appointed, as required by the by-laws (which had been otherwise disregarded also) and the sole management entrusted to the President. Upon his death the cashier, a young man of about thirty, was promoted to the vacancy, given a like freedom and within a few months absolutely wrecked the institution by loaning to himself and personal friends almost all the funds of the bank either upon unsecured notes or worthless collateral. On the board of directors who had been elected at the time of the advancement, one, $S$, an elderly man of great experience in banking, regarded himself as merely an adviser, remained upon his farm at a distance during the time of wrong-going and did not go near the bank, relying wholly upon the new President's statement that everything was going well. Another, $\mathrm{C}$, had been for a long time, and was, when elected, crippled with rheumatism and wholly unable to attend to the bank's affairs. A third, $J$, had illness in his family and remained away during these months. Chief Justice Fuller, in the prevailing opinion remarks: "It is not contended that the defendants knowingly violated or permitted the violation of any of the provisions of the banking act, or that they were guilty of any dishonesty in administering the affairs of the bank, but it is charged that they did not diligently perform duties devolved upon them by the act. It is perhaps unnecessary to atttempt to define with precision the degree of care and prudence which directors must exercise in the performance of their duties. The degree of care required depends upon the subject to which it is to be applied. They are not insurers of the fidelity

4. Butts v. Wood, 38 Barbour (N. Y.), I8x.

5. I4I U. S., I32. 
of the agents whom they have appointed, who are not their agents, but the agents of the corporation: and they cannot be held responsible for losses resulting from the wrongful acts or omissions of other directors or agents unless the loss is a consequence of their own neglect of duty, either for failure to supervise the business with attention or in neglecting to use proper care in the appointment of agents." The Court observed that by long-established usage the President and cashier had been left in exclusive charge of the bank and continued: "The evidence tends to show that the method pursued must have been and was well known to many of its customers, including those who were creditors at the time of its failure, as well as its stockholders. All this was not as it should have been and ought not to be countenanced, but the facts have an important hearing on the question whether $S$ and $J$ should be held liable because they did not at once endeavor to change the entire method of doing business and enter upon an exhaustive investigation of the assets. Would ordinarily prudent and diligent men have done so under similar circumstances?" As to $C$, the rheumatic, the Court says: "While it may be said that he should not have accepted the position of director and should not have allowed himself to be re-elected, yet upon this question of passive negligence the rule would be an exceedingly rigorous one which made no allowance for the person charged under such circumstances. We hold that directors must exercise ordinary care and prudence in the administration of the affairs of a bank, and that this includes something more than officiating as figure-heads. They are entitled under the law to commit the banking business, as defined, to their duly authorized officers, but this does not absolve them from the duty of reasonable supervision, nor ought they to be permitted to be shielded from liability becautse of want of knowledge of wrong-doing, if that ignorance is the result of gross inattention: but in this case we do not think these defendants fairly liable for not preventing loss by putting the bank into liquidation within ninety days after they became directors and it is really to that the case becomes reduced at last."

A vigorous dissenting opinion was read by Mr. Justice Harlan and it seems to the writer that the reasoning is much more sound than in that of the majority. An atmosphere of good-humored tolerance pervades the Chief Justice's opinion which is calculated to allay any uneasiness felt by indolent directors but does not seem fitted to inspire confidence in the management of our institutions.

The author of Thompson's "Commentaries on Corporations";

6. $\S 4 I I I$, note. 
disapproves of this case and the similar one of Witters $v$. Sowlcs," observing that the "decisions are unsound" and reduced to the simplest terms the conclusion from them would be that if there is to be wrong-doing in a corporation it is more prudent for a director to neglect his duty than to attend to it, especially if he can devise some plausible excuse for inaction. Even this is not always necessary as may be seen in a provision of the N'ew York Stock Corporation $\mathrm{Law}^{8}$ inposing a joint and several personal liability upon directors for declaring dividends from other than surplus profits. There are exceptions in favor of those "who may have caused their dissent therefrom to be entered at large upon the minutes of such directors at the time or cuere not present when the same happencd" as though active opposition and absence unexplained were equally pardonable! This curious and unqualified exception in behalf of nonattending directors seems very like a statute which should hold a railway switchman liable for any accident caused by his failure to set the proper signals unless he could prove that he was aslecp at his post at the tine and so unconscious of what was happening.

In the case of Warner $v$. Pcnoy' ${ }^{\circ}$ where the cashier of a small national bank had wrecked it within eighteen months by worthless discounts and the receiver brought suit against the directors the same excessive mildness was displayed. The board had appointed a discount committec consisting of the President and two directors of whom one director attended the bank two or thrce times a week to approve paper as requested by the cashier while the other clirector did nothing. The Court admitted that the President and directors did not at any time investigate or catise an investigation to be made of the bank's resources and liabilities and declared that "the directors in this case relinquished almost untrammeled control of the bank to the cashier and their supervision over its affairs was so superficial as to be liardly more than perfunctory." Nevertheless, the Court went on to say: "We are not satisfied that actionable negligence is imputable to them collectively or individually were it not found in their laxity of supcrvision over discounts. They were under no duty to observe the extraordinary vigilance short of which a bank cannot be protected from the crimes conceived by a dishonest cashier. We are of opinion that only those directors, including the President, should be held responsible for the losses who were members of the discount and examining committees. If the other

\footnotetext{
7. 3i Fed. Rep., x.

8. $\S 23$.

9. gr Fed. Rep., 587 .
} 
directors were cognizant of the neglect of duty by these directors, the proofs do not show it. As against two of the directors, the case for the complainant is predicated upon their failure to attend the semi-annual meetings of the board. It is not a necessary or legitimate inference that this omission was a contributory cause of the losses. It does not follow, because a director has failed to attend meetings, that he is legally or morally responsible for the disasters that may have befallen his bank."

These neglectful defendants were under a sworn duty to exercise an active supervision over the affairs of the bank. Great losses had been incurred by the "superficial" attention of the directors as a body and here were two who had not even taken the pains to attend the stated meetings of the board. Yet the court would impose the duty on the complainant of proving that they would have prevented the frauds by attendance! Of course, taking up the directors one by one, it would be impossible to prove that the absence of any one was a proximate cause of loss. Would it not be the better rule to hold that in the case of such frauds by an officer, all of the directors guilty of negligence were, prima facie, personally liable and the burden be placed on each one to show such facts as would exculpate him? In that event, a plea of continued absence would be an aggravation of his offence rather than an excuse. Moreover, it is astonishing that the court should have recognized a right to delegate not only the duties but the responsibilities as well of the entire board to two or three of their numbers so that the members of committees alone could be held. It is elementary that one with delegated powers cannot himself delegate his discretion but acts at his peril in so doing. It was, perhaps proper enough for the board to rid themselves of unwelcome labor by the appointment of "discount" and "examining" committees probably in accordance with the by-laws, but such committees were only agents of the entire body and there could be little harshness in holding the principals.

In still another case, Whecler $v$. Aiken County Loan \& Savings Bank et $a l,{ }^{10}$ which was a bill in equity by a stockholder against a savings bank and some of its directors, alleging mismanagement, the facts were that one director lived in another town from that in which the bank was located and asserted that his duties were performed fully by assisting the bank to secure satisfactory connections at money centers, by such occasional advice as his experience enabled him to give, and by infrequent visits. Another was a plain

ro. 75 Fed. Rep., 78 r. 
farmer who was proud of being on a board with "magnates" and although he attended meetings, he never raised any question as to the manner in which the institution was run. The Court, in denying relief, against the directors, said: "The customs and methods of the community in which the business is done are, for such community, a standard of prudence and diligence by which the responsibility of bank officers and directors is to be tested: and if there is ground to believe that there has been a reasonable conformity to such methods and customs and absolute yood faith and honesty of purpose, it would be unjust to hold to a personal accountability for loans which subsequent events proved unwise. Men of extraordinary prudence and financial foresight might have foreseen the end, but directors of a small bank in a small town cannot be justly held to personal accountability for failing to select as its managers men of extraordinary gifts. Such men are rare anywhere, and it cannot be imputed as a fault to these directors that such services were not secured for the meager salaries paid to the officials of this corporation." The Court admitted that there had been bad banking which would not stand the test of rules applied to technical trustees, but apparently felt that the duties of the directors of a small country bank were amply performed by electing an officer or two, asking a question occasionally out of idle curiosity perhaps and in maintaining a scrupulous honesty of intention.

There are some cases in which a more serious view of positive obligations of directors seems to have been taken. Thus in Gibbons v. Anderson ${ }^{11}$ which was a peculiarly flagrant instance of neglect continued through several years, during which the President squandered practically all of the assets, the Court says: "The volume of business was so small the most cursory examination by anyone having ordinary business intelligence would have disclosed the truth. - . Some of them (the cases) have gone to a length which, in my opinion, is very dangerous to public safety. . . . The idea is not to be tolerated, that they (the directors) serve as merely gilded ornaments of the institution, to enhance its attractiveness or that their reputations should be used as a lure to customers. What the public suppose and have the right to suppose is that those men have been selected by reason of their high character for integrity, their sound judgment, and their capacity for conducting the affairs of the bank safely and securely. The public act on this presumption, and trust their property with the bank in the confidence that the directors will discharge a substantial duty."12

Ir. 8o Fed. Rep., 345.

12. See comments on the question in Robinson v. Hall, 63 Fed. Rep., 222. 
The lesson to be gathered from the cases seems to be that although courts adjure directors to be good and to give some heed to the companies they have honored with their "assistance," at the present time they are not required to be familiar with the operations of the company (Wakeman v. Dalley) they need not attend meetings of the board if inconvenient to do so (Briggs v. Spauld$i n g$ ) they are not responsible for the misconduct of executive officers appointed by themselves (Wheeler $v$. Aiken Co. Bank) unless, indeed, the wrong-doing is so palpable that it is practically forced upon their attention (Gibl'ns v. Anderson) and if they persuade two or three of their number to do all the work, the latter alone will be held responsible for a neglect of such duties (Warren v. Pennoyer). Where else in human affairs may be found so admirable a combination of distinction without anxiety, of reward without toil? Would it not be well for the corporations and society at large if penalties that are admitted to be proper in the abstract were insisted upon until the prodigious number of pseudo-directors who are now in evidence were "squeezed out," and a really hard-working director, as distinguished from an officer, became less of an anomaly than he seems under present conditions?

FREDERICK DWIGHT. 